\title{
Artikel Review
}

\section{Studi Epidemiologis dan Laboratoris: Peran Metformin pada Kanker Kolorektal}

\author{
Ratih D. Yudhani \\ Bagian Farmakologi, Fakultas Kedokteran, Universitas Sebelas Maret, Surakarta, Indonesia
}

\begin{abstract}
Abstrak
Data GLOBOCAN tahun 2012 menunjukkan kanker kolorektal merupakan keganasan urutan ketiga terbanyak di dunia. Di Indonesia, berdasarkan data WHO tahun 2014, kanker ini menempati urutan kedua terbanyak pada laki-laki dan ketiga pada perempuan. Studi epidemiologis menunjukkan diabetes melitus terkait erat dengan insidensi kanker secara umum dan meningkatkan risiko kanker kolorektal sebesar 30\%. Beberapa studi epidemiologis melaporkan terapi metformin pada penderita diabetes menurunkan risiko insidensi kanker dan didukung studi laboratorik yang menunjukkan metformin mampu menghambat pertumbuhan dan proliferasi sel kanker melalui mekanisme utama mempengaruhi jalur AMPK/mTOR. Metode dalam review ini adalah penelusuran data berbasis Pubmed, Scopus dan Google Scholar dan tanpa pembatasan Index Factor dengan kata kunci metformin, colorectal cancer dan colon cancer, pada jurnal gratis maupun jurnal berbayar. Review ilmiah ini bertujuan memberikan pemahaman baru terkait aktivitas antikanker metformin dan potensinya untuk digunakan sebagai terapi preventif maupun adjuvan terapi pada kanker, khususnya kanker kolorektal.
\end{abstract}

Kata kunci: Diabetes, kanker, kolorektal, metformin

\section{Epidemiological and Experimental Studies: The Role of Metformin on Colorectal Cancer}

\begin{abstract}
GLOBOCAN data in 2012 showed colorectal cancer was the third leading cancer worldwide. In Indonesia, based on WHO data in 2014, colorectal cancer was the second common cancer ini men and third cancer in women. Epidemiological studies showed that diabetes mellitus have a correlation with the incidence of cancer and increase colorectal cancer risk by $30 \%$. Some of epidemiological study showed that metformin therapy in diabetes patient reduce the risk of cancer incidence. It supported by experimental study which showed that metformin inhibit the growth and proliferation of cancer cells by influence the AMPK/mTOR pathway as a main role. The method was literature review based on publication at Pubmed, Scopus, and Google Scholar with keywords "metformin, colorectal cancer", "metformin, colon cancer", without index factor limitation in free journal and paid journal. The aim of this review is to give a new insight of metformin activity as anti-cancer and its potential for both preventif and adjuvant cancer therapy, especially for colorectal cancer.
\end{abstract}

Keywords: Cancer, colorectal, diabetes, metformin

Korespondensi: Ratih Dewi Yudhani., dr., M.Sc, Bagian Farmakologi Fakultas Kedokteran, Universitas Sebelas Maret, Surakarta,email: rdyudhani@gmail.com

Naskah diterima: 25 Februari 2016, Diterima untuk diterbitkan: 26 Juli 2016, Diterbitkan: 1 Desember 2016 


\section{Pendahuluan}

Berdasarkan data GLOBOCAN pada tahun 2012, kanker kolorektal merupakan kanker yang menempati urutan ketiga terbanyak di seluruh dunia setelah kanker paru dan kanker payudara. Data GLOBOCAN juga menunjukkan bahwa pada tahun 2012 diperkirakan terdapat 1,4 juta kasus baru kanker kolorektal dan 55\% diantaranya terjadi di negara berkembang. ${ }^{1}$ Skrining dan surveillance sudah diterapkan sebagai prosedur standar di klinik untuk dasar deteksi dini kanker kolorektal, namun pelaksanaan pedoman ini masih rendah dan kanker kolorektal masih merupkan penyakit mematikan yang memengaruhi hidup lebih dari setengah juta orang setiap tahunnya. ${ }^{2}$ Pada tahun 2012, kanker ini mengakibatkan kematian sebesar 0,7 juta orang dan merupakan salah satu kanker dengan angka mortalitas tertinggi di seluruh dunia. ${ }^{3}$

Di Indonesia, kanker kolorektal masih merupakan masalah kesehatan yang penting. Berdasarkan data profil negara terkait kanker yang dikeluarkan WHO pada tahun 2014, kanker kolorektal merupakan keganasan yang menempati urutan kedua terbanyak pada laki-laki dengan jumlah penderita sebesar 15.985 dan urutan ketiga terbanyak pada perempuan dengan jumlah penderita sebesar 11.787. ${ }^{4}$ Penderita kanker kolorektal di Indonesia cenderung pada usia yang lebih muda dibandingkan dengan penderita di negara barat. Berdasarkan data dari Bagian Patologi Anatomi FK UI, didapatkan bahwa $35,27 \%$ penderita kanker kolorektal yang terdiagnosis, berusia di bawah 40 tahun. $^{5}$

Faktor pola makan dan gaya hidup merupakan faktor risiko kanker kolorektal. Pembatasan konsumsi daging yang dimasak maupun daging merah, digantikan dengan ikan sebagai alternatif sumber protein dan menghindari memasak daging dengan suhu tinggi merupakan beberapa strategi untuk menurunkan risiko kanker kolorektal. ${ }^{6,7}$

Selain faktor-faktor di atas, studi epidemiologis menunjukkan bahwa diabetes melitus terkait erat dengan insidensi kanker, khususnya kanker gastrointestinal. ${ }^{8,9}$ Sebuah meta-analisis yang terdiri dari 15 studi dan melibatkan total lebih dari 2,5 juta orang pada keseluruhan penelitian tersebut, menunjukkan bahwa diabetes berhubungan dengan peningkatan risiko kanker kolorektal sebesar $30 \%{ }^{10}$ Selain itu, diabetes juga secara signifikan berhubungan dengan peningkatan mortalitas kanker kolorektal secara umum (HR 1,41; CI 95\% 1,18-1,70). Kesimpulan ini diambil setelah menganalisis jenis kelamin, usia, stadium, lokasi, jenis terapi, morfologi dan grade kanker. ${ }^{11}$ Sejalan dengan hal tersebut, sistematik review dan meta-analisis dari 41 studi kohort oleh Jiang, et al. pada tahun 2011 diketahui bahwa diabetes berhubungan dengan peningkatan insiden kanker kolorektal sebesar 20\%. Peningkatan ini tidak dipengaruhi oleh jenis kelamin, Body Mass Index (BMI), riwayat kanker kolorektal pada keluarga, merokok, geografis maupun aktivitas fisik. ${ }^{12}$

Dewasa ini, hubungan antara diabetes dan kanker telah diakui secara luas, namun mekanisme yang mendasarinya belum sepenuhnya dipahami meskipun telah dilakukan beberapa studi secara intensif. Hubungan antara diabetes, terutama diabetes tipe 2 dengan kanker ini dipercaya karena kedua penyakit tersebut memiliki beberapa faktor risiko utama yang sama. Faktor risiko tersebut diantaranya proses penuaan, jenis kelamin, obesitas, inaktifitas fisik, diet, alkohol dan merokok. Selain itu, pada diabetes tipe 2, resistensi insulin dan hiperinsulinemia, baik hiperinsulinemia endogen yang terkait dengan resistensi insulin maupun hiperinsulinemia eksogen yang diinduksi oleh pemberian terapi insulin diduga merupakan faktor risiko yang menyebabkan berkembangnya kanker. ${ }^{13,14}$ Selain itu, stres oksidatif yang 
terkait hiperglikemia, akumulasi produk akhir glikasi dan inflamasi yang terjadi pada penderita diabetes juga dapat meningkatkan risiko transformasi sel ke arah keganasan. ${ }^{15,16}$

Beberapa hasil studi epidemiologis dan preklinik menunjukkan bahwa terapi metformin pada penderita diabetes terkait dengan penghambatan pertumbuhan dan proliferasi sel kanker serta reduksi insiden kanker dibandingkan dengan pasien yang mendapatkan obat hipoglikemik lain selain metformin. ${ }^{17}$ Metformin merupakan obat pilihan pertama pada beberapa konsensus karena efikasinya menyerupai obat antihiperglikemik yang lain dan memiliki rentang keamanan yang lebar, sehingga bisa diberikan pada sebagian besar pasien diabetes. Metformin dapat memperbaiki resistensi insulin, memperbaiki kontrol glikemik dan relatif aman dikombinasikan dengan obat antidiabetik dari golongan yang lain. Selain itu, metformin juga memiliki efek kardioprotektif terutama pada pasien diabetes tipe 2 dengan obesitas. ${ }^{18,19}$

Artikel ilmiah ini berisi penelusuran studi pustaka terkait peran metformin pada kanker kolorektal ditinjau dari hasil-hasil studi epidemiologis dan laboratoris. Artikel ilmiah ini bertujuan untuk memberikan pemahaman baru terkait aktivitas antikanker metformin, dan potensinya untuk digunakan sebagai terapi preventif maupun terapi adjuvan pada kanker, khususnya kanker kolorektal.

\section{Metode}

Metode yang digunakan dalam review ini adalah penelusuran data penelitian-penelitian epidemiologi maupun laboratoris terkait peran metformin pada kanker korolektal stadium I-IV berbasis Pubmed, Scopus dan Google Scholar dengan kata kunci "metformin, colorectal cancer", "metformin, colon cancer". Penelusuran tanpa pembatasan index factor, pada free journal sekitar 85,4\%
(35 dari 41) maupun jurnal berbayar sekitar 14,6\% (6 dari 41). Dari keseluruhan 41 referensi, referensi yang merupakan studi epidemiologis terkait peran metformin pada kanker kolorektal sebesar 53,7\% (22 referensi), referensi yang merupakan studi laboratoris efek antikanker metformin sebesar 26,8\% (11 referensi), dan referensi penunjang yang lain sebesar $19,5 \%$ ( 8 referensi).

\section{Hasil}

Terdapat dua studi epidemiologis yang merupakan meta-analisis kohort oleh Larsson et al., (2005) dan Jiang et al., (2011), menunjukkan bahwa diabetes berhubungan dengan peningkatan risiko kanker kolorektal sebesar 30\% dan 20\%. Hasil meta-analisis Larsson et al., dan Jiang et al., tersebut melibatkan 15 studi dan 41 studi. Dari kedua meta-analisis ini tampak hubungan diabetes dengan peningkatan risiko kanker kolorektal sangat besar dengan rata-rata 25\%. Hasil ini konsisten baik pada laki-laki maupun perempuan dan juga konsisten untuk studi-studi yang dilakukan di beberapa negara, meliputi Amerika Utara, Eropa dan Asia.

Hubungan antara metformin dengan penurunan mortalitas kanker kolorektal stadium I-IV pada pasien diabetes baik mortalitas spesifik maupun mortalitas umum dilaporkan pada 3 studi. Lee et al., (2012) dan Spillane et al., (2013) melaporkan hasil yang konsisten, bahwa metformin menurunkan mortalitas spesifik terkait kanker kolorektal pada diabetes sebesar 34\% dan 35\%. Studi oleh Spillane, et al. (2013) juga menunjukkan hasil yang konsisten, bahwa metformin menekan mortalitas umum kanker kolorektal pada diabetes sebesar $40 \%$.

Hasil-hasil studi epidemiologis tersebut didukung beberapa studi laboratoris yang menelusuri mekanisme molekuler aktivitas antikanker metfomin. Terdapat beberapa kemungkinan mekanisme aktivitas antikanker 
metformin khususnya pada kanker kolorektal yaitu melalui aktivasi AMPK (5' adenosine monophosphate-activated protein kinase), inhibisi mammalian target of rapamycin (mTOR), penurunan insulin dan insulin-like growth factor, penekanan cyclin D1, $\beta$-catenin maupun c-myc yang berperan pada proliferasi sel kankel kolorektal serta kemampuannya dalam menghambat migrasi sel kanker. Kemampuan antikanker metformin pada kanker kolorektal diduga terutama melalui pengaruhya pada jalur AMPK/mTOR.

\section{Pembahasan}

Studi Epidemiologis Peran Metformin pada Kanker Kolorektal

Penelitian terdahulu menunjukkan, rata-rata metastasis jauh pada pasien kanker kolorektal dengan diabetes melitus tipe 2 secara signifikan lebih rendah pada kelompok yang mendapatkan terapi metformin dibandingkan dengan kelompok tanpa terapi metformin, yaitu sebesar $5,60 \%$ berbanding $21,6 \%$ dengan $\mathrm{p}=0,035$. Selain itu, proporsi pasien dengan adenokarsinoma yang berdiferensiasi buruk lebih rendah pada kelompok yang mendapatkan terapi metformin dibandingkan dengan kelompok tanpa terapi metformin, yaitu sebesar $2,78 \%$ berbanding $16,0 \%$ dengan $\mathrm{p}=0,048 .^{20,21}$

Sejalan dengan penelitian di atas, Lee et al., (2012) melaporkan bahwa terapi metformin pada pasien kanker kolorektal stadium I-IV dengan diabetes selama minimal 6 bulan, menurunkan mortalitas spesifik yang terkait dengan kanker kolorektal sebesar 34\%. Dari penelitian ini juga disimpulkan bahwa terapi metformin merupakan independent predictive factor terhadap survival rate yang spesifik terkait dengan kanker kolorektal. Kesimpulan ini ditarik setelah memperhitungkan usia saat terdiagnosis, jenis kelamin, stadium kanker, Body Mass Index (BMI), lamanya mengidap diabetes, status merokok, kadar HbAlc, penggunaan aspirin, insulin, sulfonylurea dan thiazolidinedione. ${ }^{22}$

Garret et al., (2012) juga melaporkan bahwa terapi metformin pada pasien kanker kolorektal stadium I-IV dengan diabetes, secara signifikan berhubungan dengan penurunan risiko mortalitas yang umum sebesar $40 \% .^{23}$ Selain itu, terapi metformin pada pasien kanker kolorektal stadium I-III dengan diabetes menurunkan mortalitas yang spesifik terkait dengan kanker kolorektal sebesar 35\% dibandingkan dengan kelompok tanpa pemberian metformin, meskipun hasil ini tidak bermakna secara statistik $(p=0,06) .{ }^{24}$

Sejauh ini masih belum diketahui secara pasti, pada stadium berapa dan berapa lama durasi penggunaan metformin yang mampu secara efektif memengaruhi pertumbuhan tumor. Hal ini didasarkan pada metformin diduga mampu memengaruhi progesivitas jaringan normal untuk berkembang menjadi adenoma maupun kanker pada semua stadium mulai dari stadium dini sampai dengan lanjut. ${ }^{25}$

Hasil penelitian pengaruh metformin terkait dengan progesivitas adenoma pada pasien kanker kolorektal dengan diabetes telah dilaporkan oleh Kim et al., (2015). Hasil penelitian ini menunjukkan bahwa pemberian metformin selama minimal 6 bulan dapat menurunkan risiko adenoma kolorektal stadium lanjut pada pasien diabetes tanpa riwayat kanker kolorektal sebelumnya. Rata-rata insidensi adenoma stadium lanjut pada kelompok dengan metformin sebesar 0,7\% (1 dari 151 pasien), sedangkan pada kelompok tanpa metmorfin sebesar 6,7\% (6 dari 89 pasien). ${ }^{25}$ Topik insidensi adenoma kolorektal sebelumnya pernah dilakukan oleh Lee et al., (2012), namun mengambil subjek, pasien diabetes dengan riwayat kanker kolorektal sebelumnya yang telah direkseksi. Penelitian Lee et al., (2012) ini menunjukkan bahwa metformin berhubungan dengan lebih rendahnya rata-rata adenoma kolorektal pada subjek di atas dengan odds ratio 
sebesar 0,27. Hasil ini disimpulkan setelah memperhitungkan usia saat terdiagnosis, jenis kelamin, stadium kanker, BMI, riwayat kanker kolorektal pada keluarga, lamanya follow-up, jumlah total pemeriksaan kolonoskopi per pasien, interval ditemukannya adenoma dari waktu kolonoskopi pertama kali, interval dari waktu follow-up pertama kali, baseline jumlah adenoma kolorektal, modalitas terapi lain seperti aspirin, insulin dan thiazolinedinedione. ${ }^{26}$

Clinical trial prospektif pada subjek non-diabetes telah dilakukan oleh Hosono et al.,(2010). Dilaporkan bahwa pada kelompok dengan pemberian metformin dosis $250 \mathrm{mg}$ per hari selama 1 bulan, terdapat penekanan proliferasi epitelial kolon dan penurunan jumlah abberant crypt foci (ACF) dari 8,78 \pm 6,45 (baseline) menjadi $5,11 \pm 4,99(\mathrm{p}=0,007)$ dibandingkan dengan kelompok kontrol dengan penurunan dari 7,23 $\pm 6,65$ (baseline) menjadi 7,56 $\pm 6,75(\mathrm{p}=0,609)$. Pemberian metformin pada subjek non-diabetes ini tidak mengakibatkan penurunan glukosa darah maupun memengaruhi resistensi insulin, kadar kolesterol dan trigliserid plasma. Hal ini menunjukkan bahwa penekanan ACF secara langsung diakibatkan oleh metformin, tanpa melalui pengaruhnya pada resistensi insulin maupun hiperlipidemia. ${ }^{27}$

Resistensi insulin, hiperinsulinemia, stres oksidatif dan proinflamasi diduga merupakan mekanisme potensial yang menjelaskan kaitan antara diabetes melitus dengan peningkatan risiko beberapa kanker, termasuk kanker kolorektal. $^{28}$ Abnormalitas metabolisme pada diabetes tipe 2 mengakibatkan kondisi proinflamasi seperti peningkatan sitokin proinflamasi seperti tumor necrosis factor- $\alpha$ (TNF- $\alpha$ ) dan interleukin 6 serta peningkatan

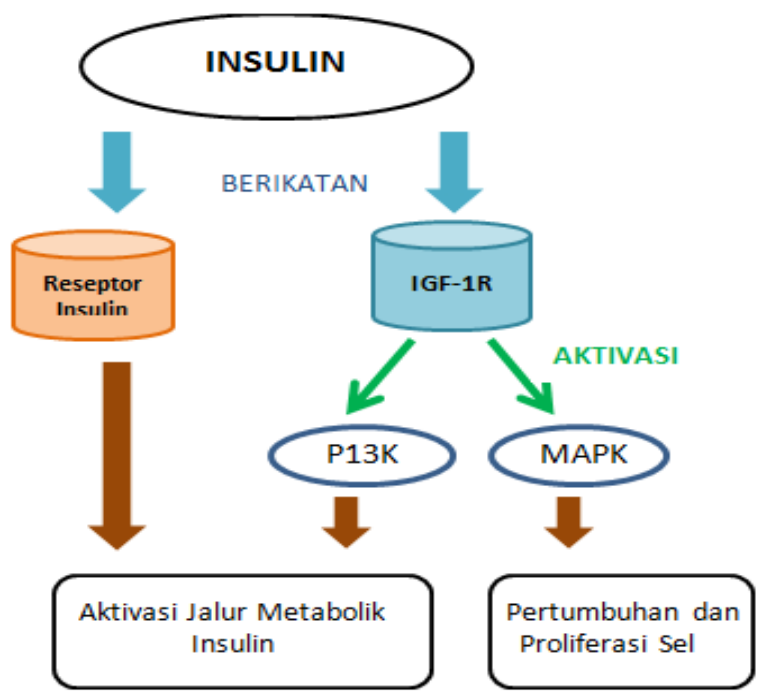

(Gambar disitasi dari Vallianou, et al. Metformin and cancer. Rev Diabet Stud. 2013;10:228-35)

IGF-1R: Insulin-like growth factor receptor 1 (Reseptor faktor pertumbuhan yang menyerupai reseptor insulin) P13K: Phosphoinositol-3-kinase pathway (Jalur kinase fosfoinositol 3)

MAPK: Mitogen-activated-protein-kinase (Protein kinase pengaktivasi pembelahan sel)

\section{Gambar 1 Mekanisme Stimulasi Proliferasi dan Aktivasi Jalur Sinyal di Tingkat Seluler oleh Insulin $^{30}$}

Keterangan: Insulin berikatan dengan reseptor insulin maupun reseptor faktor pertumbuhan yang menyerupai reseptor insulin. Ikatan ini mengaktivasi jalur kinase fosfoinositol 3 yang akan memicu jalur metabolik insulin maupun aktivasi MAPK yang akan memicu pertumbuhan dan proliferasi sel. 
stres oksidatif. TNF- $\alpha$ merupakan sitokin proinflamasi yang telah diketahui terkait dengan perkembangan dan progresi beberapa tumor. ${ }^{29}$

Insulin diduga dapatmemicu tumorigenesis baik secara langsung dengan memengaruhi jaringan epitel melalui interaksinya pada reseptor insulin/insulin-like growth factor, maupun secara tidak langsung melalui pengaruhnya terhadap modulator lain, seperti hormon seks dan adiponektin. ${ }^{18}$ Sebagian besar sel kanker mengekspresikan reseptor insulin dan insulin-like growth factor receptor I (IGF-1R) pada permukaannya. Insulin menstimulasi proliferasi dan aktivasi berbagai jalur sinyal di tingkat seluler setelah reseptor insulin maupun IGF-1R berinteraksi dengan ligandnya. Mekanismestimulasitumorogenesis oleh insulin dapat dilihat pada Gambar $1 .^{30}$
Terapi metformin menurunkan tingkat insulin/insulin-like growth factor di sirkulasi, sehingga akan menurunkan risiko timbulnya kanker. ${ }^{30}$ Terapi metformin tersebut dapat menurunkan tingkat insulin di sirkulasi melalui mekanisme aktivasi AMPK (5' adenosine monophosphate-activated protein kinase), suatu sensor energi yang berperan pada regulasi metabolisme sel, yang akan menghambat glukoneogenesis di liver. ${ }^{31}$ Aktivasi AMPK tersebut ditentukan oleh rasio AMP/ATP di tingkat seluler. Metformin dapat mengakibatkan gangguan pada rantai respirasi komplek 1 di mitokondria yang akan meningkatkan rasio AMP/ATP dan memicu aktivasi AMPK. Aktivasi AMPK ini selanjutnya akan mengaktifkan jalur katabolik yang kemudian menghasilkan ATP (seperti $\beta$-oksidasi asam lemak dan

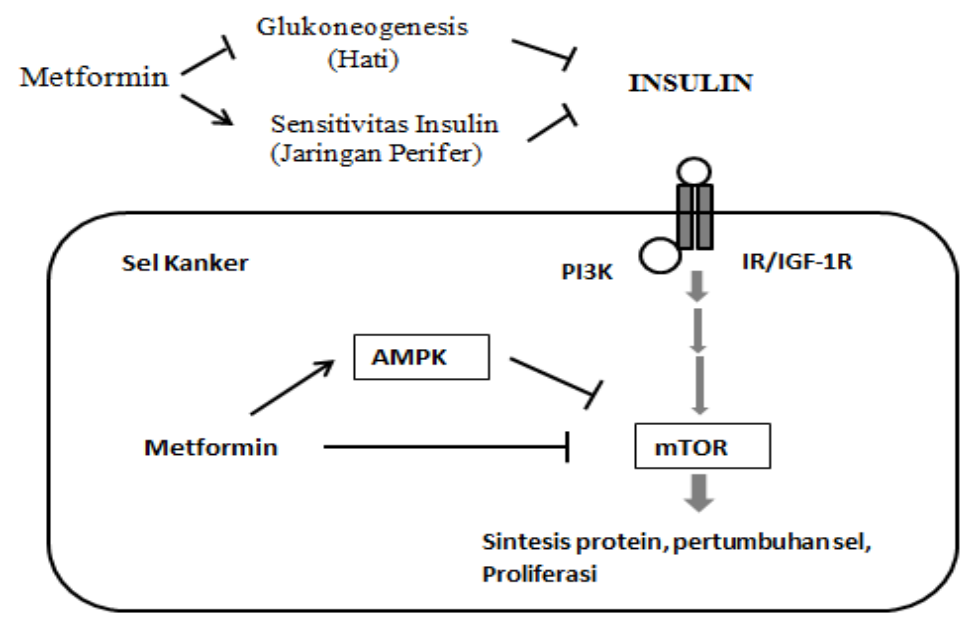

(Gambar disitasi dari Park. Metformin and cancer in type 2 diabetes. Diabetes Metab J. 2013;37:113-6) IGF-1R: Insulin-like growth factor receptor 1 (Reseptor faktor pertumbuhan yang menyerupai reseptor insulin) P13K: Phosphoinositol-3-kinase pathway (Jalur kinase fosfoinositol 3)

AMPK: Adonosine Monophosphat Activated Protein Kinases (Protein Kinase Pengaktivasi AMP) mTOR: mammalian Target of Rapamycin

\section{Gambar 2 Mekanisme Penghambatan Karsinogenesis oleh Metformin ${ }^{34}$}

Keterangan: Metformin melalui aktivasi AMPK menghambat glukoneogenesis di liver dan menstimulasi uptake glukosa di jaringan perifer melalui peningkatan sensitivitas insulin. Hal ini akan menurunkan insulin di sirkulasi dan mengurangai ikatan insulin dengan reseptor insulin maupun IGF-1R yang akan menghambat aktivasi transduksi sinyal pada sel kanker. Proses ini selanjutnya akan menekan pertumbuhan dan proliferasis sel kanker. 
glikolisis) serta menekan konsumsi ATP melalui penghambatan glukoneogenesis, sintesis protein, sintesis asam lemak dan biosintesis kolesterol. ${ }^{32}$ Penghambatan glukoneogenesis oleh AMPK yang teraktivasi ini akan mengurangi output glukosa dari liver dan menurunkan glukosa di sirkulasi. Hal ini mengakibatkan terjadinya penurunan insulin di sirkulasi. ${ }^{31}$ Selain itu, metformin juga memperbaiki sensitivitas insulin di jaringan perifer sehingga akan menurunkan hiperinsulinemia. Resistensi insulin dan hiperinsulinemia juga dipercaya merupakan faktor yang terkait dengan peningkatan risiko timbulnya beberapa jenis kanker, khususnya kanker kolorektal. ${ }^{33}$ Mekanisme metformin dalam menghambat karsinogenesis pada diabetes dijelaskan pada Gambar 2.

Studi Laboratoris Peran Metformin pada Kanker Kolorektal

Beberapa studi preklinik menunjukkan bahwa metformin mampu menekan proliferasi, memicu apoptosis, mengakibatkan berhentinya siklus sel dan mengurangi insidensi serta menghambat pertumbuhan beberapa tumor pada penelitian eksperimental. ${ }^{35}$ Sebuah studi in vitro menunjukkan bahwa metformin mampu menghambat proliferasi sel kanker kolorektal. Hasil ini didukung oleh studi in vivo yang melaporkan bahwa metformin mampu menghambat onset pertumbuhan tumor pada tikus model kanker kolorektal dengan mutasi p53. Selain itu, pemberian metformin pada duajenis hewan model dengan abberant crypt foci (ACF) kolorektal mampu menekan proliferasi sel epitelial kolon secara signifikan melalui mekanisme inhibisi jalur mammalian target of rapamycin (mTOR). ${ }^{30}$

Metformin mampu menghambat mTOR melalui regulasi beberapa jalur. Rendahnya energi sebagai akibat terapi metformin pada kanker akan mengaktivasi AMPK yang akan menghambat pertumbuhan dan proliferasi sel. Hal ini terjadi karena aktivasi AMPK akan mengaktivasi gen penekan tumor sehingga menghambatmTOR, yang merupakan regulator proliferasi sel dan juga memicu apoptosis. ${ }^{36}$

Penelitian lainnya melaporkan bahwa metformin mampu menghambat proliferasi cell line SW480 (sel kanker kolorektal) yang sebanding dengan peningkatan dosis dan lama waktu pemberian. Efek penghambatan proliferasi cell line SW480 ini terkait dengan penekanan ekspresi cyclin D1 dan penghambatan aktivitas telomerase oleh metformin. ${ }^{37,38}$ Cyclin D1 merupakan protein regulator yang diperlukan untuk progresi dan transisi siklus sel dari fase G1/S masuk ke dalam fase $\mathrm{S}$ (sintesis). ${ }^{39}$

Dalam upaya untuk menemukan strategi terapi baru dalam melawan kanker kolorektal metastatik maupun rekuren, Makker et al., (2014) melakukan penelitian untuk menilai efektivitas kombinasi metformin dengan kemoterapi standar untuk kanker kolorektal, yaitu Fluorouracil dan Oxaliplatin (Fu-Ox). Hasil penelitian secara in vitro menunjukkan bahwakombinasiMetformindanFu-Ox secara sinergis mampu menghambat pertumbuhan cell lines HCT-16 dan HT-29 (cell lines kanker kolorektal yang kemoresisten). ${ }^{35}$ Efek kombinasi metformin dan Fu-Ox dalam menghambat pertumbuhan kanker ini juga dapat ditunjukkan secara in vivo. Kombinasi terapi tersebut mampu memperkecil volume kanker pada hewan coba (mencit xenogratf) yang diinduksi oleh cell lines HCT-16 dan HT-29. Mekanisme hambatan proliferasi dan pertumbuhan sel kanker kolorektal oleh kombinasi metformin dan Fu-Ox melalui mekanisme penekanan ekspresi $\beta$-catenin dan c-myc pada sel kanker kolorektal kemoresisten (HCT-16). Jalur Wnt- $\beta$-catenin ini sebelumnya telah dipercaya, merupakan jalur yang berperan penting pada regulasi proriferasi dari sel kanker kolorektal. ${ }^{35}$

Kombinasi metformin dan Fu-Ox juga mampu menghambat migrasi sel kanker kolorektal, sehingga menjanjikan untuk 
dikembangkan sebagai strategi terapi dalam menghambat metastasis kanker kolorektal. Penghambatan migrasi sel kanker ini diperantarai melalui mekanisme penekanan miRNA 21. ${ }^{35} \mathrm{Lu}$ et al., (2008) melaporkan bahwa miRNA 21 meregulasi pertumbuhan, migrasi, invasi dan apoptosis sel kanker. Selain itu, dalam penelitiannya, Volinia et al., (2006) melaporkan bahwa ekspresi miRNA 21 mengalami peningkatan pada kanker kolorektal. ${ }^{40,41}$ Berdasarkan hal ini, kombinasi metformin dan $\mathrm{Fu}-\mathrm{Ox}$ dipercaya mampu menghambat migrasi kanker kolorektal, salah satunya melalui mekanisme penekanan ekspresi miRNA.

\section{Simpulan}

Hasil studi epidemiologis menunjukkan, terdapat hubungan antara diabetes dengan peningkatan risiko kanker terutama kanker kolorektal dan pemberian metformin terbukti berperan dalam menurunkan risiko kanker tersebut pada penderita diabetes. Studi laboratoris menunjukkan bahwa mekanisme molekuler kemampuan metformin sebagai antikanker ini diperantarai melalui perannya dalam memengaruhi jalur sinyal seluler terutama jalur AMPK/mTOR. Keseluruhan data-data di atas mendukung efek antikanker metformin. Studi pada tahap klinik terkait potensi antikanker metformin maupun potensi kombinasi metformin dengan agen kemoterapi standar dirasa sangat diperlukan sebagai upaya pengembangan metformin, sehingga untuk kedepannya diharapkan dapat diterapkan di klinik untuk terapi preventif maupun adjuvan bagi penderita kanker, khususnya kanker kolorektal.

\section{Ucapan Terima Kasih}

Terima kasih kepada dr. Amandha Boy Timor yang telah membantu dalam review tata bahasa.

\section{Pendanaan}

Review ilmiah ini tidak didanai oleh sumber hibah manapun.

\section{Konflik Kepentingan}

Penulis menyatakan tidak terdapat potensi konflik kepentingan dengan penelitian, kepenulisan (authorship), dan atau publikasi artikel ini.

\section{Daftar Pustaka}

1. Ferlay J, Soerjomataram I, Dikshit R, Eser S, Mather C, Rebelo M, Parkin DM, et al. Cancer incidence and mortlity worldwide: sources, methods and major pattern in GLOBOCAN 2012. Int $\mathrm{J}$ Cancer. 2015;136(5):E359-86. doi: 10.1002/ijc. 29210

2. Jemal A, Bray F, Center MM, Ferlay J, WardE, Forman D. Globalcancerstatistics. CA Cancer J Clin. 2011;61(2):69-90. doi: 10.3322/caac. 20107

3. Siegel R, Ma J, Zou Z, Jemal, A. Cancer statistics. CACancer J Clin. 2014;64(1):929. doi: 10.3322/caac. 21208

4. World Health Organization (WHO). Cancer country profiles 2014 [diunduh 15 Juni 2016].Tersedia dari:http://www.who. int/cancer/country-profiles/idn_en.pdf

5. Abdullah M. Tumor Kolorektal. Buku ajar ilmu penyakit dalam jilid III edisi VI. Jakarta: Interna Publising; 2014.

6. Norat T, Bingham S, Ferrari P, Slimani $\mathrm{N}$, Jenab M, Mazuir M, et al. Meat, fish, and colorectal cancer risk: The European prospective investigation into cancer and nutrition. J Natl Cancer Inst. 2005;97(12):906-16. doi: 10.1093/jnci/ dji164

7. Robertson DJ, Sandler RS, Haile R, Tosteson TD, Greenberg ER, Grau $M$, et al. Fat, fiber, meat and the 
risk of colorectal adenomas. Am J Gastroenterol. 2005;100(12):2789-95. doi: 10.1111/j.1572-0241.2005.00336.x

8. Lee MS, Hsu CC, Wahiqvist ML, Tsai $\mathrm{CN}$, Chang YH. Type 2 diabetes increases and metformin reduces total, colorectal, liver, and pancreatic cancer incidences in taiwanese: a representative population prospective cohort study of 800.000 individuals. BMC Cancer. 2011;11:20-9. doi: 10.1186/1471-2407-11-20.

9. Chiu CC, Huang CC, Chen YC, Chen TJ, Liang Y, Lin SJ, et al. Increased risk of gastrointestinal malignancy in patient with diabetes mellitus and correlations with anti-diabetes drug: a nationwide population-based study in Taiwan. Intern Med. 2013;52(9):939-46. doi: 10.2169/ internalmedicine. 52.8276

10. Larsson SC, Orsini N, Wolk A. Diabetes mellitus and risk of colorectal cancer: a meta-analysis. J Natl Cancer Inst. 2005;97(22):1679-87. doi: 10.1093/jnci/ dji375

11. Bella F, Minicozzi P, Giacomin A, Crocetti E, Federico M, Ponz dLM, et al. Impact of diabetes on overall and cancer-spesific mortality in colorectal cancer patients. J Cancer Res Clin Oncol. 2013;139(8):1303-10. doi: 10.1007/ s00432-013-1439-8

12. Jiang Y, Ben Q, Shen H, Lu W, Zhang Y, Zhu J. Diabetes mellitus and incidence and mortality of colorectal cancer: a systematic review and meta-analysis of cohort studies. Eur J Epidemiol. 2011;26(11):863-76. doi: 10.1007/ s10654-011-9617-y

13. Smith U, Gale EM. Cancer and diabetes: are we ready for prime time? Diabetologia. 2010;53(8):1541-4. doi: 10.1007/s00125-010-1815-8

14. Giovannucci E, Harlan DM, Archer MC, et al. Diabetes and cancer: a consensus report. Diabetes Care. 2010;33(7):1674-
85. doi: $10.2337 / \mathrm{dc} 10-0666$.

15. Azar M, Lyons TJ. Diabetes, insulin treatment and cancer: what is the evidence?. Med Rep. 2010;2:4. doi: 10.3410/M2-4

16. Drzewoski J, Drozdowska A, Sliwinska A. Do we have enough data to confirm the link between antidiabetic drug use and cancer development?. Pol Arch Med Wewn. 2011;121(3):81-7.

17. Kasznicki J, Sliwinska A, Drzewoski J. Metformin in cancer prevention and therapy. Ann Transl Med. 2014;2(6):1-11. doi: 10.3978/j.issn.2305-5839.2014.06.01

18. Decensi A, Puntoni M, Goodwin P, CazzanigabM, Gennari A, Bonanni $\mathrm{B}$, et al. Metformin and cancer risk in diabetics patients: a sysitematic review and meta-analysis. Cancer Prev Res. 2010;3(11):1451-61. doi: 10.1158/19406207.CAPR-10-0157

19. Raz, I. Guideline approach to therapy in patients with newly diagnosed type 2 diabetes. Diabetes Care. 2013;36(2):13944. doi: $10.2337 / \mathrm{dcS} 13-2035$

20. Chung HH, Moon JS, Yoon JS, Lee HW, Won KC. The relationship between metformin and cancer in patients with type 2 diabetes. Diabetes Metab. 2013;37(2):125-31. doi: 10.4093/ dmj.2013.37.2.125

21. Zhang ZJ, Zheng ZJ, Kan H, Song Y, Cui W, Zhao G, etal. Reduced risk of colorectal cancer with metformin therapy in patients with type 2 diabetes: a meta-analysis. Diabetes Care. 2011;34(10):2323-8. doi: $10.2337 / \mathrm{dc} 11-0512$

22. Lee JH, Kim TI, Jeon SM, Hong SP, Cheon $\mathrm{JH}$. The effect of metformin on the survival of colorectal cancer patients with diabetes melitus. Int J Cancer. 2012;131(3):75259. doi: 10.1002/ijc.26421

23. Garret CR, Hassabo HM, Bhadkamkar NA, Wen S, Baladandayuthapani V, Kee BK. Survival advantage observed with 
the use of metformin in patients with type II diabetes and colorectal cancer. Br J Cancer. 2012;106(8):1374-8. doi: 10.1038/bjc.2012.71

24. Spillane S, Bennett K, Sharp L, Barron T. A cohort study of metformin exposure and survival in patients with stage I-III colorectal cancer. Cancer Epidemiol Biomarkers Prev. 2013;22(8):1364-73. doi: 10.1158/1055-9965.EPI-13-0347

25. Kim YH, Noh R, Cho SY, Park SJ, Jeon SM, Shin HD, et al. Inhibitory effect of metformin therapy on the incidence of colorectal advanced adenoma in patients with diabetes. Intest Res. 2015;13(2):14552. doi: 10.5217/ir.2015.13.2.145

26. Lee JH, Jeon SM, Hong SP, Cheon JH, Kim TI, Kim WH. Metformin use is assosiated with a decreased incidence of colorectal adenomas in diabetic patients with previous colorectal cancer. Dig Liver Dis. 2012;44(12):1042-7. doi: 10.1016/j. dld.2012.06.007

27. Hosono K, Endo H, Takahashi H, Sugiyama M, Sakai E, et al. Metformin suppresses colorectal abberant crypt foci in short-term clinical trial. Cancer. Pres Res (Phila). 2011;3(9):1077-83. doi: 10.1158/1940-6207.CAPR-10-0186

28. Tseng $\mathrm{CH}$. Diabetes, metformin use, and colon cancer: a population-bsed cohor study in Taiwan. Eur J Endocrinol. 2012;167(3):409-16. doi: 10.1530/EJE12-0369

29. Szlosarek P, Charles KA, Balkwill FR. Tumor necrosis factor-alpha as a tumour promoter. Eur J Cancer. 2006;42(6):74550. doi: 10.1016/j.ejca.2006.01.012

30. Vallianou NG, Evangelopoulos A, Kazazis C. Metformin and cancer. Rev Diabet Stud. 2013;10(4):228-35. doi: 10.1900/RDS.2013.10.228

31. Shaw RJ, Lamia KA, Vasquez D, Koo SH, Bardeesy N, DePinho RA, et al. The kinase LKB1 mediates glucose homeostasis in liver and therapeutic effects of metformin. Science. 2005;310(5754):1642-6. doi: $10.1126 /$ science. 1120781

32. Barriere G, Tartary M, Rigaud $M$. Metformin: A rising star to fight the epithelial mesenchymal transition in oncology. Anti-cancer Agents Med Chem. 2012;13(2):1-8. doi: $10.2174 / 187152061131302001$

33. Ioannou GN, Boyko EJ. Metformin and colorectal cancer risk in diabetic patients. Diabetes Care. 2011;34(10):2336-7. doi: $10.2337 / \mathrm{dc} 11-1447$

34. Park HK. Metformin and cancer in type 2 diabetes. Diabetes Metab J. 2013;37(2):113-6. doi: 10.4093/ dmj.2013.37.2.113

35. Makker PN, Yu Y, Vasudevan A, Farhana L, Rajendra SG, Levi E, et al. Metformin: a potential therapeutic agent for recurrent colon cancer. Plos One. 2014;9(1):e84369. doi: 10.1371/journal. pone.0084369

36. Pernicova I, Karbonits M. Metforminmode of action and clinical implications for diabetes and cancer. Nat Rev Endocrinol. 2014;10(3):143-56. doi: 10.1038/nrendo.2013.256

37. Zhou XZ, Xue YM, Zhu B, Sha JP. Effects of metformin on proliferation of human colon carcinoma cell line SW-480. J South Med Univ. 2010;30(8):1935-42.

38. Zhou XZ, Xue YM, Gao F, Zhu Bo, Guan MP. Effect and mechanism of metformin on AGEs-induced proliferation of colon carcinoma cell line SW-480. Chin J Diabetes. 2012;20(7):546-8.

39. Baldin V, Lukas J, Marcote MJ, Pagano M, Draetta G. Cyclin D1 is a nuclear protein required for cell cycle progression in G1. Genes Dev.1993;7(5):812-21. doi: 0.1101/gad.7.5.812

40. Lu Z, Liu M, Stribinskis V, Klinge CM, Ramos KS. MicroRNA-21 promotes cell transformation by targeting the 
programmed cell death 4 gene. Oncogene. 2008;27(31):4373-9. doi: 10.1038/ onc. 2008.72

41. Volinia S, Calin CA, Liu CG, Ambs S, Cimmino A, Petrocca F, et al. A micro-
RNA expression signature of human solid tumors defines cancer gene targets. Proc Natl Acad Sci. 2006;103(7):2257-61. doi: 10.1073/pnas.0510565103 